que contienen invocaciones a la Virgen María, ésta queda sustituida por la diosa Venus. La parodia, sin embargo, no se limita estrictamente a la glosa de los rezos litúrgicos. Hay, en primer lugar, una constante actitud de adoración a Cupido y a Venus. En segundo lugar, aparecen (como en casi todas las obras de este género) algunos ilustres personajes "canonizados" en el reino de Cupido, como Tristán, Lanzarote y otros leales amadores (copla 11), a los cuales se suman las figuras ejemplares de $\mathrm{Ma}$ cías el Enamorado² (copla 17) y de Paris y Elena (copla 20). Por último, se alude a la palma de martirio que tienen los que mueren en la "ley" del Amor (18f), al galardón celestial que otorga Venus a las "buenas obras" de los amantes (copla 21), y a la intercesión de los "santos y santas" de la corte de Cupido (copla 10).

A. Alatorre

El Colegio de México.

\title{
COMENTARIOS ESTILÍSTICOS SOBRE UNA RIMA DE BÉCQUER
}

En el presente estudio trataré de rastrear la presencia en las Rimas de un mensaje estructurado a base de entidades lingǘsticas, y de señalar la importancia de éstas para la expresión. El objeto de arte y de expresión en estos poemas es la lengua misma; y su mensaje más profundo se revela a través de distintos tipos o clases de relación entre sus elementos lingüísticos. En todo propósito expresivo, el poeta se ve limitado a apuntar signos gráficos en el papel. Para mejor llamar la atención del lector sobre los elementos específicos de su mensaje, tiene que fijar dentro del poema o contexto una norma. Sin embargo, después de asentada la norma, razones de expresión y de estilo le obligan a romperla -procedimiento estilístico que se llama "ruptura del sistema". Investigaré sólo algunos de estos rasgos estilísticos con el fin de aclarar su importancia dentro de la técnica y de la emotividad becquerianas.

Leamos la primera estrofa de la Rima LIII, verso tras verso, fijando nuestra atención en el significado que nos comunican sus elementos sintácticos. Si la lectura sigue sin novedad en sentido semántico-sintáctico, es decir, si en el nivel sintáctico los significantes se pliegan dócil e inequívocamente a sus correspondientes significados, no habrá -en este nivel, por lo menos- una ruptura del sistema. Principiamos la lectura de la Rima LIII con la misma finalidad con que leemos cualquier otro documento. A las indicaciones gráficas del contexto tratamos de asignar desde el primer momento posible un sentido, concepto o idea. Según Ferdinand de Saussure, el signo lingüístico encierra dos componentes inseparables: el significado o contenido semántico, y el significante o representación acústica -o gráfica en el caso de la comunicación por escrito.

El primer verso - "Volverán las oscuras golondrinas"- carece de

2 El consejo puesto en boca de Macías: "que por trabajos que vea, / quien con amores guerrea / que sienpre muestre plazer", es seguramente un recuerdo de la canción por excelencia del poeta gallego: "Loado seas, amor, / por quantas penas padeço...", recordada por Garci Sánchez de Badajoz y por Gregorio Silvestre (ć. C. Martínez-Barbeiro, Macias el Enamorado y Juan Rodriguez del Padrón, Santiago de Compostela, 1951, pp. 35 y 39). 
rupturas sintácticas: no parece contener $\sin _{0}$ un verbo (Volverán) seguido de su sujeto gramatical (las oscuras golondrinas). Sin embargo, al terminar la lectura del segundo verso nos damos cuenta de una posible ruptura del sistema o de la norma establecida en el primer verso:

Volverán las oscuras golondrinas

en tu balcón sus nidos a colgar...

¿Cuáles son las funciones sintácticas de los elementos Volverán, a y colgar? ¿Se trata de un verbo principal más un complemento indirecto que indica propósito? ¿O se trata, más bien, de una frase verbal en que Volverán... $a$ expresa un sentido reiterativo, un tiempo verbal y un número plural, y en que la acción descansa sobre el infinitivo colgar? ¿Significa Volverán... a colgar que las golondrinas volverán 'para' colgar sus nidos, o significa que los colgarán 'de nuevo"?

Como se ve, la ruptura no es brusca ni tampoco decisiva. El segundo verso no corrige ni anula la interpretación del primero, sino que añade otra perspectiva semántica. En este lugar del contexto nos encontramos con dos posibilidades significativas, con dos rutas sintácticas. Nuestra experiencia lingüística nos dice que, en muchos casos de ambigüedad, el escritor o el hablante no tardan en disipar nuestras dudas, dando indicaciones que favorezcan la aceptación de una sola de dos interpretaciones como la única correcta. Así, al terminar de leer el segundo verso de la Rima LIII el lector atento aguardará la solución de esta dificultad semántico-sintáctica. En los versos tercero y cuarto:

$$
\begin{aligned}
& \text { y otra vez con el ala a sus cristales } \\
& \text { jugando llamarán..., }
\end{aligned}
$$

el mismo sujeto gramatical golondrinas está regido por otro verbo en tiempo futuro, que lleva un complemento de sentido reiterativo: otra vez. . llamarán. El verbo de este grupo se vincula por razones de analogía con Volverán: ambos son verbos principales del mismo tiempo, persona y número. Por otra parte, el predominante sentido reiterativo de otra vez... llamarán (= 'volverán a llamar') lo asocia fuertemente a Volverán... a colgar en su acepción de frase reiterativa. Al terminar de leer la primera estrofa, la ambigüedad sintáctico-semántica de Volverán... a colgar sigue en pie.

La primera antistrofa:

pero aquellas que el vuelo refrenaban tu hermosura y mi dicha a contemplar, aquellas que aprendieron nuestros nombres... ésas. . ¡ ¡no volverán!

contiene un grupo - refrenaban... a contemplar- cuyo verbo, sumado al complemento indirecto de propósito, fortalece por analogía sintáctica la misma interpretación para Volverán. . a colgar. Con todo, a pesar de las constantes fluctuaciones asociativas o rupturas que los elementos mencionados ejercen sobre Volverán. . . a colgar, ya como verbo principal 
más complemento de propósito, ya como frase verbal reiterativa, la ambigüedad no se resuelve sino en las palabras finales de la antistrofa: no volverán, donde se pone de manifiesto la función de Volverán. . a colgar como verbo principal seguido de un complemento de propósito.

Otros factores expresivos aumentarán la dinámica tensión entre los dos polos significativos de Volverán. . a colgar antes de resolverse esta dualidad. Volverán... a colgar, en su acepción de verbo principal más complemento indirecto, efectuará una honda transformación en la imagen las oscuras golondrinas. Bajo esta interpretación, la imagen queda como humanizada: las golondrinas se acercarán intencionadamente, como si fueran amantes suyos, al balcón de la amada. El sujeto gramatical desempeña el papel poético - por indirecto- de concretar a través de la imagen la actitud del poeta hacia la amada y hacia los objetos relacionados con ella. Pero ese valor "anímico" de la imagen no se aclara de manera definitiva sino al final de la primera antistrofa. Mientras tanto, aumentan la tensión y la expectación provocadas por las dos posibilidades significativas aún no resueltas en unidad; y con ellas, aumenta también la emoción del lector.

En cuanto frase verbal reiterativa, Volverán... a colgar añade valores reiterativos a un contexto ya repleto de ellos, acumulando sentidos de repetición dentro de dos acciones futuras y una en tiempo pasado que destacarán, por antítesis, el valor poético y emotivo del acto no repetido (no volverán). En este sentido es importante notar el hecho de que tampoco en Volverán como verbo principal deja de manifestarse el sentido reiterativo, puesto que volver se siente como 'venir otra vez' o 'venir de nuevo'.

El empleo del sentido ambiguo de Volverán... a colgar corresponde a una manifestación sutilísima de un procedimiento típicamente becqueriano: el "final explicativo". Carlos Bousoño, descubridor de esta característica, la explica así refiriéndose a las Rimas $I I$ y X: "El sentido de las sucesivas estrofas habría permanecido como en el aire, flotando entre varias aguas o posibilidades significativas, indeciso, hasta que, por último, se fija en una aclaratoria finalización". Bousoño llama también la atención sobre la "atmósfera de entusiasmo provocada por la ansiedad a que el procedimiento obliga"'.

Gran parte del aparato semántico-sintáctico ya estudiado se repite en la segunda estrofa y en su correspondiente antistrofa, pero su presencia en el tercer conjunto se limita a unos cuantos elementos esenciales:

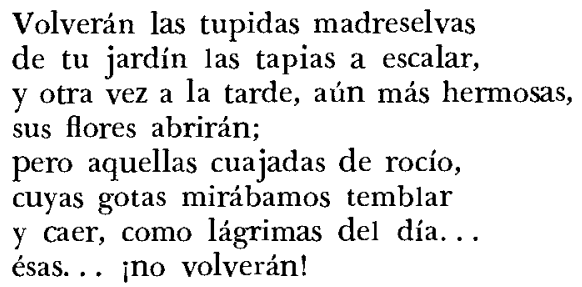

Volverán las tupidas madreselvas de tu jardín las tapias a escalar, y otra vez a la tarde, aún más hermosas, sus flores abrirán; pero aquellas cuajadas de rocío, cuyas gotas mirábamos temblar y caer, como lágrimas del día... ésas. .. ¡no volverán!

\footnotetext{
${ }^{2}$ Carlos Bousoño, "Las pluralidades paralelisticas de Bécquer", en Seis calas en la expresión literaria española, por Dámaso Alonso y Carlos Bousoño, Madrid, 1951, pp. $214^{-215}$.
} 
Volverán del amor en tus oídos

las palabras ardientes a sonar;

tu corazón de su profundo sueño tal vez despertará;

pero mudo y absorto y de rodillas, como se adora a Dios ante su altar, como yo te he querido...., desengáñate, ¡nadie así te amará!

Estas repeticiones constituyen un paralelismo sintáctico o formal. "Llamamos paralelismo formal - dice Bousoño- a la coincidencia de los miembros semejantes en la forma (casi siempre en una categoría gramatical estricta)". Ahora bien, "todo paralelismo en la forma encierra paralelismo en los conceptos", y "los paralelismos no son otra cosa que una variante del procedimiento reiterativo, que consiste en repetir el género común próximo de cada uno de los miembros que forman un conjunto" (loc. cit., pp. 207-209). Bousoño ha encontrado ejemplos de paralelismos en veintiocho de las setenta y seis Rimas de la primera edición (1871).

Relacionados con el paralelismo sintáctico o formal, y fortaleciéndolo, encontramos muchos otros tipos de reiteración, a saber: la anáfora de vocablos o de sus partes, el número de sílabas del elemento sintáctico, el lugar silábico del acento rítmico, la repetición de las mismas partes de la oración, la posición estrófica del sintagma, la rima y la cantidad silábica entre acentos rítmicos ${ }^{2}$. Mediante una intencionada voluntad de estilo, los distintos tipos reiterativos embellecen a los grupos sintácticos y, al mismo tiempo, ponen de relieve no sólo su sentido dentro de la oración, sino también sus relaciones paralelísticas interestróficas. El lector se habitúa a la constante identificación entre los distintos tipos reiterativos. Es decir, esa asociación se constituye en norma estilística. Una de las características más acusadas de las Rimas es la súbita e inesperada desviación de algún elemento de esta norma. Una vez seducido el lector por el influjo asociativo del paralelismo sintáctico, el poeta no tarda en introducir elementos sintácticos que de ninguna manera se pueden aceptar como repeticiones sintácticas dentro de sus oraciones respectivas. Un bello ejemplo de este procedimiento nos lo brinda la Rima LIII con el trio en tu balcón, de tu jardin, en tus oidos. El primero y el tercero son complementos circunstanciales que desempeñan, cada uno en su oración, papeles análogos. El segundo no es complemento circunstancial, sino una frase preposicional que especifica el complemento directo tapias. Entre en tu balcón y de tu jardin hay varias semejanzas: las mismas partes de la oración (preposición, adjetivo posesivo, sustantivo que indica lugar), el mismo número de palabras y de sílabas, el mismo lugar silábico del acento rítmico y la misma posición del elemento sintáctico

- Este último tipo de semejanza es importante porque constituye una manera de repetición sin que los grupos tengan necesariamente la misma acentuación silábica dentro de sus respectivos versos. Por ejemplo, "tu corazón de su profundo sueño" es el único verso de la Rima $L I I I$ con acentos rítmicos en la cuarta y octava sílabas (o-o-o-ó o-o-o-ó o-ó-o). Sin embargo, el esquema rítmico o-o-o-ó (tres sílabas átonas seguidas de una acentuada) se repite en otras partes del poema: "en tu balcón", "aquéllas que aprendié/ron nuestros nómbres", "las oscúras golondrinas", "jugándo llamarán", etc. 
dentro del verso y de la estrofa. Bécquer nos hace seguir la norma ya establecida de aceptar por iguales en contenido sintáctico varios significantes que son iguales en su forma gráfica, rítmica, de posición, etc.

Veamos si, fuera de los tipos de paralelismo ya mencionados, hay alguna semejanza conceptual entre en tu balcón y de tu jardin. La preposición $d e$, además de su función de indicar la posesión, tiene la de significar "los objetos o atributos que están contenidos en una persona o cosa: los árboles de este jardin, etc."3 Es decir, "los árboles de este jardín" equivale a 'los que están en este jardín'. De hecho, el sentido conceptual más preciso de las tapias de tu jardin es 'las tapias (que están) en tu jardín'. Sin comprometerse en lo más mínimo la calidad sintáctica oracional de en tu balcón como complemento circunstancial ni la de de tu jardin como especificación del complemento directo las tapias, el vínculo reiterativo establecido entre estos dos elementos opera de tal modo, que el lector los entiende a ambos como complementos circunstanciales de lugar. Aunque después se aclara la verdadera función de de tu jardin, no deja de registrarse primeramente en la mente un sentido sin base en la sintaxis oracional, un sentido sugerido por el contagio de otros muchos tipos de semejanza. Este hecho constituye una ruptura del sistema. Durante un momento, al menos, se llega a crear no sólo un sentido, sino una pareja de aparente semejanza "sintáctica" entre dos elementos sintácticamente diferentes. El paralelismo formai entre estrofas se aprovecha, pues, para la creación de sentidos o significaciones que trascienden el mero aparato lógico de la oración gramatical.

El lector llega al tercer conjunto paralelístico con la norma estilística ya establecida en las dos oleadas paralelísticas anteriores, y supone, por ejemplo, que Volverán... a sonar formará parte de una nueva repetición sintáctica. Se trata de los siguientes grupos: 'las oscuras golondrinas volverán a colgar sus nidos en tu balcón'; 'las tupidas madreselvas volverán a escalar las tapias de tu jardín'; 'las palabras ardientes del amor volverán a sonar en tus oídos'. Pero el conjunto 3 no termina con el no volverán que ha resuelto la ambigüedad sintáctico-semántica de los conjuntos 1 y 2. Interpretamos Volverán... a sonar como una frase verbal reiterativa que rompe con el patrón de los conjuntos 1 y 2. En esta ruptura se destaca de nuevo la presencia de un elemento que, debido al contagio asociativo del paralelismo formal interestrófico, parece tener un sentido y una función sintáctica que no caben dentro de la oración a que pertenece. Por otra parte, en cuanto al paralelismo de imágenes, parece algo forzado atribuir al sujeto palabras ardientes el valor "anímico" de las otras imágenes. Como en el caso de de tu jardin, el paralelismo formal sirve para sugerir sentidos y funciones sintácticas no justificadas dentro de la oración.

Partiendo de la norma estilística planteada en términos de oración gramatical, y desde el punto de vista de sus rupturas y ambigüedades, se atisban momentos claros en el proceso creativo de la rima becqueriana. Hay, como dice la Rima III, "Ideas sin palabras, / palabras sin sentido". El elemento de tu jardín ofrece un ejemplo de "idea sin palabras", puesto que la "idea" que sugieren los lazos asociativos tendidos

\footnotetext{
3 Samuer Grli Gaya, Curso superior de sintaxis española, México, 1943, p. 225
} 
por la reiteración (en tu balcón, de tu jardin, en tus oidos) no se basa en "palabras", es decir, en voces de significado preciso e inequívoco dentro de la oración gramatical. De la misma manera, "palabras sin sentido" son los elementos que por ambiguos carecen en un momento dado de sentido preciso: Volverán... a colgar.

El paralelismo formal no sólo sirve para intensificar la emoción a base de repeticiones de un género común, sino que hace posible la comunicación de ideas creadas al margen de la trabazón lógico-gramatical de la oración. Las discrepancias entre la forma y la idea engañan y sugieren, informan y deleitan al lector. El encanto de las Rimas no se debe a la mera repetición de categorías, sino a la cualidad, la función y la disposición de tipos a veces comunes y a veces diferentes. El ritmo, la rima, la imagen, el concepto, la forma gramatical y la gráfica se funden y se separan en múltiples combinaciones, produciendo una constante tensión y una belleza originalísima entre los polos significativos de la fantasía y la lógica.

Robert J. YounG, JR.

Indiana University.

\section{ADICIONES A "CAMINO DEL POEMA (CONFIANZA DE PEDRO SALINAS)"}

Raimundo Lida nos ha ofrecido en su artículo "Camino del poema", Fil, 5 (1959), 95-117, una elucidación magistral -se puede decir: clásicade la génesis del poema "Confianza» de Pedro Salinas, siguiendo paso a paso los ocho estados que nos ofrecen los borradores conservados del poeta mismo e insertando el poema en su tradición poética (Garcilaso, Góngora, Bécquer ${ }^{1}$, Rubén Darío). A otro amante de la poesía de Sa-

1 También se podría extender el tópico habrá poesia a la edad antigua, donde encontramos un dum (donee) anafórico dicho de cosas de la naturaleza y de la historia que duran, o que se suponen durar, eternamente, condición que sirve para ensalzar la gloria -eterna- de poetas o de seres amados:

Ovidio, Amores, 1, 15,7 ss:

Mortale est, quod quaeris, opus. Mihi fama perennis quaeritur, in toto semper ut orbe canar.

Viuet Maeonides [Homero], Tenedos dum stabit et Ide, dum rapidas Simois in mare uoluet aquas.

Viuet et Ascraeus [Hesíodo], dum mustis uua tumebit, dum cadet incurua falce resecta Ceres...

Tityrus et fruges Aeneiaque arma legentur, Roma triumphati dum caput orbis erit.

Donee erunt ignes arcusque Cupidinis arma, discentur numeri, cuite Tibulle, tui.

Horacio, Carmina, III, $3^{\circ}$ (Exegi monumentum):

Non omnis moriar multaque pars mei uitabit Libitinam: usque ego postera crescam laude recens, dum Capitolium scandet cum tacita uirgine pontifex. 